\title{
MOTIF ORANG TUA SANTRI DI PONDOK PESANTREN HM LIRBOYO
}

\author{
Oleh: \\ Marzuki \\ Ahmad Masrukin \\ marzukiahmad225@gmail.com \\ Institut Agama Islam Tribakti (IAIT) Kediri
}

\section{Abstrak}

Tulisan ini bermaksud menjelaskan motif yang mendasari orang tua memilih pondok pesantren sebagai tempat pendidikan anaknya. Metode penelitian yang digunakan adalah kualitatif fenomenologi dengan subjek penelitian orang tua santri, pengurus pondok pesantren, dan santri. Hasil penelitian menyimpulkan alasan yang mendasari memilih pondok pesantren adalah pertama, alasan agama dan ideologis, yaitu orang tua santri berharap anaknya dapat meneruskan kiprah perjuangan mereka di masyarakat dengan mengajarkan Islam Ahlusunah wal Jama'ah. Konsep moderasi Islam selalu diajarkan dalam pesantren, mereka para alumni dapat diterima dengan mudah oleh masyarakat. Kedua, lingkungan keluarga dan masyarakat. Orang tua menyadari tentang kondisi di sekitar mereka dengan berbagai bentuk kenakalan remaja yang berpengaruh pada perilaku anaknya. Mereka tidak dapat mengatasi persoalan itu secara sendiri, alternatif mengatasi persolan itu orang tua memilih anaknya untuk belajar di pondok pesantren. Ketiga, pendidikan dalam pondok pesantren. Selain belajar formal, di pondok pesantren ada kegiatan pembelajaran lain, aturan dan pengawasan. Setiap hari di pondok pesantren diisi dengan berbagai kegiatan, dalam bentuk madrasah, jam'iyyah, musyawarah, mengaji, muratil dan lainnya. Kegiatan yang ketat dibarengi dengan aturan yang ketat. Berbagai aturan dibuat untuk mengatur santri pada setiap harinya. Dalam waktu 24 jam santri melakukan berbagai aktivitas. Terakhir ada pengawasan dari pengurus, santri 
mendapatkan pengawasan, setiap pelanggaran yang dilakukan oleh santri akan mendapatkan teguran, peringatan bahkan takzir dari pengurus.

Kata Kunci: Motif Orang Tua, Santri.

\section{Pendahuluan}

Keluarga merupakan lingkungan utama dalam pembentukan kepribadian seorang anak. Masa awal pertumbuhannya lebih banyak dihabiskan di dalam lingkungan keluarga. Dalam kehidupan keluarga orang tua bertanggungjawab atas kehidupan keluarga dan memberikan pengarahan yang benar yaitu dengan menanamkan ajaran agama dan akhlakul karimah. Selama orang tua bisa melaksanakan tugasnya dengan baik, maka anak tidak akan mudah dipengaruhi oleh apapun. ${ }^{1}$ Kepribadian anak akan bergantung pada lingkungan keluarga. Oleh karena itu anak yang hidup pada lingkungan keluarga yang baik akan membentuk karakter yang baik pula, dan sebaliknya.

Banyak kasus kenakalan remaja yang sering terjadi karena banyaknya krisis moral seperti pencurian, tawuran remaja, perkelahian, pembegalan, dan pelecehan seksual. Kasus-kasus yang sering terjadi pada anak, salah satu penyebabnya adalah kurangnya perhatian dari keluarga, lingkungan, dan sekolah. ${ }^{2}$ Banyak juga orang tua yang khawatir akan masa depan putra-putrinya. Hal tersebut dikarenakan semakin banyaknya kasus criminal, perkelahian pelajar, penyalahgunaan narkoba, minum-minuman keras, dan lain sebagainya. Oleh karenanya, banyak keluarga yang berpikir

${ }^{1}$ Hasby Wahyi, "Keluarga Sebagai Basis Pendidikan", Jurnal Ilmiah Didaktika, 2 (Februari, 2012), h. 245-258

2 Zubaidi, Desain Pendidikan Karakter (Jakarta: Kencana Pernada Media Group, 2012), h,1-2.

Volume 30 Nomor 1 Januari-Juni 2019 
ulang tentang nilai efektifitas pendidikan umum dalam mengembangkan kepribadian dan moral anak. ${ }^{3}$

Dalam konteks ini, banyak orang tua yang melirik pondok pesantren dalam mengarahkan pendidikan moral anak. Pada saat anak berada di pondok pesantren, orang tua telah memberikan tanggung jawab sepenuhnya kepada pihak pondok pesantren untuk menjaga anaknya, membimbing dan membina moral, serta memberikan ilmu agama agar anaknya kelak menjadi individu yang sesuai harapan agama, bangsa, dan negara. Seorang santri ketika berada di pondok pesantren harus mengikuti semua kegiatan yang ada di pondok pesantren dan menaati segala peraturan yang telah ditetapkan oleh pondok pesantren. Apabila santri melanggar peraturan yang ada di pondok pesantren maka akan mendapatkan hukuman sesuai dengan pelanggaran yang dilakukannya. Hal ini berbeda ketika seorang anak berada di rumah, anak akan bersikap manja dan seringkali melanggar peraturan yang telah dibuat oleh orang tuanya, dan tidak sedikit pula orang tua yang begitu saja lepas tangan dalam mengurusi anaknya. Tak jarang dari mereka ada yang tidak pulang sampai azan subuh. Namun orang tua mereka sudah tidak sanggup lagi mengingatkan anaknya.

Banyak pondok pesantren, menjadi alternatif lain di tengah kegalauan orang tua dalam menentukan lembaga pendidikan yang sesuai bagi putra-putri mereka. Hal yang membedakan dari materi pendidikan pesantren dengan pendidikan umum adalah, seorang santri terlebih dahulu dibekali pendidikan moral atau etika. Tahapan ini sangat penting, mengingat etika atau adab merupakan pondasi bagi kesuksesan dalam belajar, "mencari ilmu". Nabi SAW. berpesan, Adibni

3 Mamlukhah, "Motivasi Orang tua Memilih Pondok Pesantren Sebagai Sarana Pendidikan Moral Anak", Jurnal Darussalam; Jurnal Pendidikan, Komunikasi dan Pemikiran Hukum Islam,.2 (April, 2017), h. 95109 
Robbi fa Ahsin ta'dibi. Allah SWT mendidikku dan menjadikan pendidikanku ( $t a$ 'dib) yang terbaik. ${ }^{4}$ Fenomena semacam ini telah merata di berbagai daerah. ${ }^{5}$ Terlebih ketika pesantren menjadi tempat yang tepat dalam mengimplementasikan pendidikan karakter. ${ }^{6}$

Manusia akan selalu memiliki pertimbangan dalam melakukan perbuatan atau tindakan. Oleh sebab itulah setiap manusia akan memiliki motif, tujuan, atau keinginan. Motif inilah yang akan mendorong seseorang untuk berbuat atau bertindak. Hal ini akan berlaku pada perilaku manusia secara umum. Termasuk tindakan orang tua dalam memilih lembaga pendidikan yang tepat untuk anaknya tidak bisa dilepaskan dari adanya motif. Di antaranya motif ideologi, motif edukasi, motif strukturalis, motif ekonomi dan motif pragmtis. ${ }^{7}$

Ada tiga persepsi atau pandangan masyarakat terhadap pesantren, sebagai lembaga sosial, karena kehidupan di pesantren sejatinya sama seperti kehidupan yang ada di lingkungan masyarakat. Sebagai lembaga pendidikan, pondok pesantren adalah salah satu lembaga pendidikan yang menyelenggarakan model pembelajaran full day school. Sebagai pusat ilmu agama, pondok pesantren mempunyai ciri khas sebagai pendidikan yang dalam porsi pendidikannya lebih mengunggulkan pada bidang agama. ${ }^{8}$

${ }^{4}$.Sayid Naquib Alatas, Islam and Secularism dalam Sungai tak Bermuara,(Jakarta: Diwan, 2006) hal.

151.

5 Rahma Dani Pudji Astuti, "Perubahan Pondok Pesantren Modern di Perkotaan", Masyarakat; Jurnal Sosiologi. 2 ( Juli, 2017), h. 257-279.

6 A. Jauhar Fuad, "Pendidikan Karakter Dalam Pesantren Tasawuf" Jurnal Pemikiran Keislaman, Vol. 23 No. 1 Januari 2012, h. 60.

${ }^{7}$ Erdiyanti,, "Fenomena Orangtua dalam memilih lembaga pendidikan Islam”, Jurnal Fenomenologi, No.2, (Februari, 2012), h.30

${ }^{8}$ Erdiyanti," "Fenomena Orangtua dalam memilih lembaga pendidikan Islam”, Jurnal Fenomenologi, No.2, (Februari, 2012), h. 22 
Berdasarkan pada persolan di atas maka tulisan ini bermaksud mengungkap berbagai motif orang tua asal Indramayu memilih pondok pesantren sebagai tempat belajar anaknya? Bagaimana interaksi santri asal Indramayu di lingkungan pondok pesantren?

\section{Pembahasan}

\section{Motif Orang Tua dalam Mendidik Anak}

Istilah motif mempunyai banyak arti sesuai konteks penggunaannya. Dalam tulisan ini istilah motif bermakna alasan seseorang melakukan sesuatu. ${ }^{9}$ Arti ini mempunyai dimensi psikologis tapi bukan berarti istilah motif sama persis dengan motivasi dalam kajian psikologi. Untuk menghindari kesalahpahaman penggunaan kedua istilah itu, ada baiknya untuk sedikit mengulasnya secara bersamaan. Bagi Sardiman, motivasi berasal dari kata motif. Motif berarti daya upaya yang mendorong seseorang melakukan sesuatu. Dari definisi ini, maka motivasi berarti daya penggerak yang telah menjadi aktif. ${ }^{10}$ Dengan kata lain, motif merupakan langkah awal atau persiapan awal dari munculnya motivasi. Implikasinya adalah motif dan motivasi mempunyai makna yang saling terkait meskipun pada dasarnya memiliki perbedaan arti. Dengan demikian, motif dalam tulisan ini berarti alasan orang tua dalam menentukan pendidikan anaknya.

Orang pertama dan utama yang mempunyai peran dalam mengasuh dan mendidik anak adalah orang tua. Tanggung jawab orang tua dalam mendidik anak dimulai pada lingkungan rumah tangga. ${ }^{11}$ Akan tetapi seorang anak akan terus mengalami

9 "Hasil Pencarian - KBBI Daring," accessed February 2, 2018, https://kbbi.kemdikbud.go.id/entri/motif.

10 Sardiman, A.M, Interaksi dan Motivasi Belajar Mengajar (Jakarta: Rajawali Pers, 2014), h. 73.

11 Zakiati Salma, "Tanggungjawab Orangtua Dalam Membentuk Kepribadian Anak Perspektif Alquran dan Psikologi," AL QUDS : Jurnal Studi Alquran 170

Volume 30 Nomor 1 Januari-Juni 2019 
perkembangan menuju masa remaja dan dewasa sehingga pemberian pendidikan anak mengalami peralihan pada lembaga pendidikan. Pada tahap ini, orang tua masih mempunyai peran untuk mengarahkan pendidikan anaknya agar seluruh potensi kemanusiaan dalam diri anak dapat berkembang secara maksimal sebagai bekal kehidupan anak di masa mendatang. Ini juga bukan berarti orang tua sudah melepaskan diri dari tugas dan tanggung jawabnya untuk mendidik anak. Justu proses itu juga melibatkan peran dan pertimbangan orang tua.

Di sini motif orang tua bisa berbeda-beda. Tapi umumnya orang tua mempunyai maksud yang sama yaitu untuk mendidik anaknya menjadi pribadi yang baik dalam segala potensinya yang mencakup kepribadian, akhlak, intelektual dan keterampilan. Motif orang tua tentunya mengarah pada dimensi antisipasi atas dampak negatif perkembangan zaman, lingkungan, dan pemikiran yang mungkin mempengaruhi anaknya. Secara historis banyak cerita kenabian yang dapat dijadikan pelajaran dan alasan bagi orang tua dalam berusaha untuk mendidik anak.

Cerita yang masyhur tentang kegagalan mendidik anak telah diberikan sejak kegagalan Nabi Nuh AS dalam mendidik putranya yang bernama Kan'an. ${ }^{12}$ Cerita ini bisa dijadikan sebagai salah satu pengingat dan alasan bagi semua orang tua dalam berusaha mendidik anaknya, terlepas dari hasil usaha tersebut. Di samping itu, dalam tulisan ini penulis hanya memfokuskan pada motif orang tua yang menyekolahkan anaknya di pondok pesantren atau di lembaga pendidikan berbasis pesantren. Jadi dalam tulisan ini, penulis tidak mempersoalkan tentang pola pengasuhan orang tua yang banyak

\footnotetext{
dan Hadis 1, no. 1 (June 27, 2017): 67-80, https://doi.org/10.29240/alquds.v1i1.183.

12 Idam Mustofa, "Komitmen Orang Tua Dalam Pendidikan Anak," Intizam, Jurnal Manajemen Pendidikan Islam 2, no. 1 (October 25, 2018): 23-38. 
diklasifikasikan secara berlawanan antara pengasuhan atau peran orang tua otoriter dan demokratis. Karena pada dasarnya semua orang tua menginginkan yang terbaik untuk anaknya. Salah satu cara yang ditempuh adalah dengan mengarahkan pendidikan anak agar tumbuh menjadi manusia yang baik secara lahiriah dan batiniah.

\section{Motif Orang Tua Asal Indramayu Memilih Pondok Pesantren}

Pada umumnya orang tua asal Indramayu, khususnya yang berasal dari Kecamatan Krangkeng dengan berbagai profesi dan status sosial, baik pekerja, pengusaha dan tokoh agama sangat mengkhawatirkan pergaulan remaja yang ada di sekitarnya. Mereka beranggapan bahwa lingkungan pendidikan yang ada di sekitar rumah bahkan di sekolah umum sudah mulai terpengaruh oleh pergaulan-pergaulan yang tidak baik. Hal tersebut menuntut mereka untuk menyekolahkan anaknya di pondok pesantren, baik pesantren modern atau pesantren salaf. Menurut pandangan orang tua pondok pesantren adalah satu-satunya lembaga pendidikan yang dapat menyelamatkan putra-putrinya dari lingkungan yang tidak karuan tersebut.

Di Kecamatan Krangkeng banyak alumni dari Pondok Pesantren Haji Mahrus (HM) Lirboyo. Orang tua cenderung memiliki minat untuk memasukan anaknya ke pondok Pesantren HM Lirboyo. Baik dari keluarga alumni maupun yang bukan alumni. Setiap orang tua memiliki pertimbangan dan alasan sendiri-sendiri yang menurutnya tepat bagi anaknya. Di antara motif tersebut adalah sebagaimana berikut. Pertama, alasan agama dan ideologis. Bapak H. Tosin selaku wali santri asal Indramayu dari desa Kedungwungu mengemukakan alasannya memilih pondok pesantren HM Lirboyo karena pemahaman agama yang diajarkan di pondok pesantren HM adalah kitabkitab Ahlussunah wal-Jama'ah. Baginya pondok pesantren HM 
sudah menjadi pilihan keluarganya sejak dulu sebagaimana penuturannya berikut ini:

Akhir-akhir ini pondok pesantren mulai dipercaya sebagai tempat terbaik oleh orang tua di desa saya. Mungkin karena lingkungan sudah sedemikian rupa kacaunya. Anak saya saja yang sering diketati tetap terpengaruh dengan teman. Susah diajak ngaji atau sekolah madrasah. Padahal bagi saya pemahaman agama itu penting supaya tidak dibingungkan oleh paham-paham yang lain. Saya sudah banyak tahu tentang alumni pondok pesantren HM Lirboyo. Ketika berkiprah di masyarakat selalu memberikan solusi hukum yang ringan dan mudah dan selalu memberikan referensi-referensi dari kitab mu'tabarah. Oleh karena itu saya tertarik memondokkan anak saya di pondok ini. Supaya ketika meneruskan perjuangan saya di rumah bisa memiliki banyak referensi yang berpaham Ahlussunah wal Jama'ah. Di desa saya pernah kecolongan ada keluarga yang asal memondokkan anak ternyata anaknya malah jadi teroris. ${ }^{13}$

Penjelasan di atas menunjukkan sikap antisipasi orang tua karena banyak orang terlibat kasus terorisme dan gerakangerakan yang mengatasnamakan Islam untuk kepentingan tertentu. Kedua, lingkungan di rumah yang kurang baik. Dalam hal Bapak Masrukhan selaku wali santri asal Indramayu dari desa Kedungwungu mengutarakan bahwa:

Di daerah saya anak kecil sudah banyak yang merokok, padahal usianya masih empat belas tahun, mungkin baru SD kelas enam. Dengan kondisi tersebut anak saya rupanya terpengaruh jadi ikut ngerokok. Padahal selama anak saya masih SD kelas enam, saya sudah keras dalam mendidik anak, tapi tetap saja susah diatur. Orang tua

13 Wawancara dengan Bapak. H. Tosin di ruang tamu PP. HM pada tanggal 12 Juli 2018 jam 11.00-11.30 wis 
sekitar sini banyak yang memondokkan anaknya. Akhirnya saya paksa anak saya supaya mau mondok, ternyata dia mau di pondok HM, setelah saya selidiki ternyata ikut oleh teman-temannya. Bagi saya pribadi asal anak di pondok sudah seneng, minimal kalau kumpul dengan orang-orang benar kan kebawa benar, karena kalau di rumah pasti sekolahnya tidak akan karuan. ${ }^{14}$

Uraian di atas menujukkan bahwa orang tua mempunyai kekhawatiran akan maraknya problem-problem anak muda, bahkan anak di bawah umur. Ini juga merupakan sikap antisipasi orang tua agar anaknya tidak mudah terjerumus pada kehidupan yang negatif dan tidak sesuai dengan ajaran agama. Ketiga, aturan yang ketat dalam pondok pesantren. Hal ini disampaikan oleh Bapak Kalil selaku wali santri asal Indramayu dari Desa Srengseng. Beliau menyampaikan sebagaimana berikut :

Akhir-akhir ini kehidupan remaja di desa saya semakin tidak karuan mas. Hampir setiap hari, tidak siang tidak malam saya sering menjumpai/remaja yang masih sekolah SMP, SMA atau setingkatnya pada merokok, mabuk, ngoplos. Kejadian penjambretan dan pembegalan di sepanjang wilayah Indramayu sering terjadi. Kebanyakan pelakunya adalah pelajar yang masih sekolah SMP, SMA. Saya khawatir anak saya terlibat oleh lingkungan yang demikian. Apalagi setiap hari saya harus bekerja. Jarang ketemu sama anak. Ketika Dzuhur biasanya saya baru pulang sering kali anak saya gak ada di rumah, dan jika ada malah susah diatur. Tidak mau berangkat ngaji dan salat ke mushalla. Kerjaannya nongkrong-nongkrong tidak jelas. Biasanya kalau habis Maghrib pergi sama temen-temennya dan pulangnya jam dua belas malam. Padahal anak saya baru kelas I SMP.

14 Wawancara dengan Bapak. Maksudi di ruang tamu PP. HM pada tanggal 20 Maret 2018 jam 10.00-10.30 wis 
Menghadapi anak saya yang begini, saya jadi iri ketika melihat anak adik saya yang di pondok pesantren HM, anaknya nurut sering membantu orang tua. Pada waktu liburan saya tanya-tanya tentang PP. HM kepada keponakan saya, kemudian saya bujuk anak saya agar mau mondok di PP. HM, awalnya minta pondok pesantren yang deket, tapi saya menolak khawatir tidak ada yang mengawasi dan malah sering pulang. Kalau di PP. HM kan ada saudaranya jadi bisa diawasi terus dan kalau ada kekurangan dalam hal apapun bisa dipinjamkan dulu. ${ }^{15}$

Alasan yang hampir sama juga disampaikan oleh Bapak. Nasruddin selaku wali santri asal Indramayu dari desa Tegalmulya. Beliau menyampaikan alasannya memilih pondok pesantren HM Lirboyo karena pengawasannya ketat dan santrinya tidak neko-neko.

Saya paham betul dengan anak saya. Dulu ketika sekolah di madrasah yang ada di rumah sering tidak berangkat. Kadang dari rumah berangkat tapi malah main dengan teman-temannya. Saya berharap supaya anak saya bisa mengerti ilmu agama. Mengingat anak saya tidak memungkinkan untuk didik di sekitar rumah. Makanya setelah lulus SD saya pondokkan dengan teman-temannya di Pondok HM. Karena saya tahu dari para alumni katanya kondisi pondoknya ketat selalu diawasi oleh pengurus jadi santri tidak bisa neko-neko ketika di pondok. Dengan begitu saya lega. Karena kalau di pondok lain anak saya tidak mau, mungkin karena teman-temannya banyak yang

15 Wawancara dengan Bapak. Kalil di Ruang Tamu PP. HM tanggal 16 Juli 2018 jam 08.00-08.40 wis 
melanjutkan di sini. Tapi saya sebagai orang tua juga harus tau pondoknya bagaimana. ${ }^{16}$

Keempat, ada pengawasan dari pengurus pada setiap kegiatan. Bapak H. Maksudi selaku wali santri asal dari Kecamatan Krangkeng Indramayu mengungkapkan 'pondok pesantren HM Lirboyo dalam setiap kegiatan selalu dikawal oleh pengurus, sehingga kegiatan belajar mengajarnya akan berjalan dengan lancar.

Sebelum saya ke Lirboyo, saya tanya-tanya tentang pondoknya kepada para alumni. Kebanyakan mengarahkan ke sini kareana di pondok ini banyak teman sedaerah yang bisa membantu anak saya dalam belajar dan sebagainya. Dan setiap program yang ada di pondok pesantren HM katanya selalu dikawal oleh para pengurus. Baik kegiatan pondok, madrasah atau pun kegiatan kemasyarakatan seperti jam'iyyah. Oleh karena itu kemudian saya bawa anak saya kesini. Dengan adanya upaya yang baik dalam pengawasan, saya berharap anak saya rajin di pondok supaya bisa naik kelas dan bisa membaca kitab, karena pada pondok sebelumnya anak saya malas-malasan dan tidak naik kelas. Mungkin karena kurangnya pengwasan dari pengurus. ${ }^{17}$

Kelima, banyak program kegiatan yang bervariasi. Bapak Yanuki selaku wali santri yang berasal dari Desa Kedungwaru, Indramayu mengungkapkan alasannya memilih pondok pesantren HM Lirboyo karena program yang ada sangat beragam.

Pondok HM memiliki alumni yang banyak. Di daerah saya mayoritas adalah alumni PP.HM. Menurut para alumni, di

${ }^{16}$ Wawancara dengan Bapak. Nasruddin di ruang tamu PP. HM pada tanggal 24 maret 2018 jam 11.30-12.00.

17 Wawancara dengan Bapak. H. Tosin di ruang tamu PP. HM pada tanggal 23 Maret 2018 jam 10.00-10.30 wis 
HM tempatnya lebih nyaman dan rapi, fasilitasnya memadai, sekolahnya tetap di MHM. Banyak program kegiatan yang cocok dengan saya. Sekalipun mayoritas orang tua di desa saya hanya menginginkan anaknya benar. Tapi saya tidak hanya itu, selain benar juga ingin supaya paham kitab-kitab dan dapat mengamalkannya. Pertama kali saya tau PP. HM ketika ziarah Wali Songo, kebetulan ketua ziarahnya alumni PP. HM jadi mampir, menurut saya pondoknya ketat, akhirnya ketika anak saya lulus SD saya pondokkan di sini. Supaya bisa disiplin dalam melakukan kegiatan. Kalau tidak di pondok yang ketat saya khawatir anak saya malah nganggur dan bebas bermain. Di sini juga enak kalau ada permasalahanpermasalan yang berkaitan dengan anak saya ada tetangga yang sudah jadi pengurus. Jadi setiap kali ada apa pun akan diurus oleh tetangga saya. ${ }^{18}$

Tiga alasan di atas menunjukkan bahwa orang tua mempunyai ketertarikan, pengetahuan, dan pengalaman tentang tradisi dan sistem pembelajaran di pesantren. Motif terakhir yaitu, meneruskan tradisi keluarga. Bapak Karduki selaku wali santri asal Indramayu dari kecamatan Krangkeng. Alasan beliau memilih pondok pesantren HM Lirboyo adalah karena meneruskan tradisi keluarga. Pondok pesantren HM sudah menjadi pilihan keluarganya sejak dulu. Dalam wawancaranya dengan peneliti beliau menyampaikan sebagaimana berikut :

Keluarga saya dulu mondoknya di PP. HM semua, termasuk saya. Maka saya paham betul bagaimana pendidikan yang ada di sini. Dengan adanya anak saya di sini saya bertujuan untuk meneruskan tradisi yang ada di keluarga saya. Selain itu juga supaya saya bisa sering sowan kepada pengasuh Lirboyo, karena kalau tidak ada

18 Wawancara dengan Bapak. Yanuki di ruang tamu PP. HM pada tanggal 21 Maret 2018 jam 09.00-09.30 wis 
hal-hal yang menuntut untuk kesini biasanya malas. Banyak alumni yang tidak pernah sowan ke Lirboyo mulai sejak tamatan sampai sekarang. Kebanyakan karena anaknya tidak mondok di sini. ${ }^{19}$

Uraian orang tua santri di atas menjelaskan berbagai alasan mereka dalam memilih dan mengarahkan pendidikan anak. Seluruh alasan itu ada yang murni untuk kepentingan anak, dan ada juga yang secara disadari atau tidak mengarah pada kepentingan pribadi orang tua untuk menjaga tradisi keluarga dengan cara mengarahkan pendidikan anaknya. Namun secara umum, alasannya bertumpu pada sikap antisipasi atas maraknya problem moral yang dialami generasi bangsa, khususnya anak-anak dan generasi muda.

\section{Penutup}

Orang tua santri mempunyai motif berbeda-beda dalam menentukan pendidikan anaknya. Penelitian ini menemukan beberapa motif orang tua yang menjadi dasar alasan mereka dalam menyekolahkan anak di pesantren. Dari beberapa motif yang muncul, peneliti membaginya ke dalam enam faktor. Pertama, alasan agama dan ideologi. Alasan ini didorong oleh kekhawatiran orang tua karena banyaknya gerakan-gerakan yang menggunakan agama sebagai basisnya. Kedua, problem lingkungan sekitar yang berpotensi membuat anak terbawa pada hal-hal yang bersifat negatif sejalan dengan perkembangan teknologi informasi. Ketiga, aturan yang ketat dalam pondok pesantren. Ini menjadi salah satu kelebihan pesantren dalam mendidik santri dalam melatih diri menjadi pribadi yang disiplin dalam kehidupan keseharian mereka.

Keempat, ada pengawasan dari pengurus pada setiap kegiatan. Alasan ini juga sangat khas pesantren karena setiap

19 Wawancara dengan Bapak. Karduki di ruang tamu PP. HM pada tanggal 24 Maret 2018 jam 11.00-11.30 wis 
aturan diusahakan berlaku secara menyeluruh. Kelima, banyak program kegiatan yang bervariasi. Alasan ini sangat berkaitan dengan dua faktor sebelumnya. Dengan banyaknya kegiatan, santri akan disibukkan untuk belajar dan bersosialisasi dengan santri lain di lingkungan pesantren. Ini merupakan jalan pembentukan kepribadian dan kebiasaan santri agar menjadi manusia yang tidak bermalas-malasan dan melupakan berbagai hal remeh temeh yang pada akhirnya dapat menghambat perkembangan belajar kepribadian mereka.

Keenam, meneruskan tradisi keluarga. Ini salah satu faktor unik dan penuh tantangan karena menjaga tradisi banyak dianggap sebagai sesuatu yang dianggap kaku dan penyematan label negatif lainnya. Padahal menjaga tradisi itu adalah sesuatu yang penting dan sulit untuk dilakukan meskipun tujuan dan niatnya baik. 


\section{DAFTAR PUSTAKA}

Alatas, Syed Naquib. Islam and Secularism dalam Sungai tak Bermuara. Jakarta: Diwan, 2006.

AM, Sardiman. Interaksi dan Motivasi Belajar Mengajar. Jakarta: Rajawali Pers, 2014.

Astuti, Rahma Dani Pudji. "Perubahan Pondok Pesantren Modern di Perkotaan". Masyarakat; Jurnal Sosiologi. 2 ( Juli, 2017).

"Hasil Pencarian - KBBI Daring." Accessed February 2, 2018. https://kbbi.kemdikbud.go.id/entri/motif

Erdiyanti. "Fenomena Orangtua/dalam memilih lembaga pendidikan Islam". Jurnal Fenomenologi, No.2, (Februari, 2012).

Fuad, A. Jauhar. "Pendidikan Karakter Dalam Pesantren Tasawuf". Jurnal Pemikiran Keislaman, Vol. 23 No. 1 Januari 2012.

Kalil. Wawancara. Kediri, 16 Juli 2018.

Karduki. Wawancara. Kediri, 24 Maret 2018.

Maksudi. Wawancara. Kediri, 20 Maret 2018.

Mamlukhah. "Motivasi Orang tua Memilih Pondok Pesantren Sebagai Sarana Pendidikan Moral Anak". Jurnal Darussalam; Jurnal Pendidikan, Komunikasi dan Pemikiran Hukum Islam,.2 (April, 2017).

Mustofa, Idam. "Komitmen Orang Tua Dalam Pendidikan Anak." Intizam, Jurnal Manajemen Pendidikan Islam 2, no. 1 (October 25, 2018): 23-38.

Nasruddin. Wawancara. Kediri, 24 maret 2018.

Salma, Zakiati. "Tanggungjawab Orangtua Dalam Membentuk Kepribadian Anak Perspektif Alquran dan Psikologi." AL QUDS : Jurnal Studi Alquran dan Hadis 1, no. 1 
Motif Orang Tua... Oleh: Marzuki \& A. Masrukin

(June 27, 2017): 67-80.

https://doi.org/10.29240/alquds.v1i1.183.

Tosin. Wawancara. Kediri, 12 Juli 2018.

Wahyi, Hasby. "Keluarga Sebagai Basis Pendidikan”. Jurnal Ilmiah Didaktika, 2 (Februari, 2012).

Yanuki. Wawancara.Kediri, 21 Maret 2018.

Zubaidi. Desain Pendidikan Karakter. Jakarta: Kencana Prenada Media Group, 2012. 